Journal of Applied Youth Studies

https://doi.org/10.1007/s43151-020-00015-3

BOOK REVIEW

\title{
Sarah Pickard: Politics, Protest and Young People
}

Pickard, S. (2019), Politics, Protest and Young People: Political Participation and Dissent in 21st

Century Britain. London: Palgrave Macmillan. 501 pages.

\section{Julius Elster}

Published online: 20 August 2020

Conflict of interest statement: On behalf of all authors, the corresponding author states that there is no conflict of interest.

The important premise that generalistic, homogeneous and deterministic tendencies should be avoided when portraying youths threads its way through Sarah Pickard's lucidly written Politics, Protest and Young People. Pickard shares this premise with the growing body of youth studies literature, which increasingly aims to understand youths in heterogeneous ways and dispel the myths about young people as apathetic. The same cannot be said about the approach adopted by large sections of the British media and polity, especially with respect to understanding young people's political participation. Pickard's long-term research project does not only shed light on how the mainstream media and the political elite repeatedly neglect the rich plurality of political engagement across the youth demographic, she also seeks out an alternative approach to the dominant one. Divided into 15 chapters, the book's interdisciplinary perspective weaves together several thematic and empirical strands, where both qualitative and quantitative analyses are 
employed (inspired by Einstein's maxim that 'not everything that can be counted counts and not everything that counts can be counted'). The result is a realistic account of, and a versatile toolbox for understanding, politically-committed young people inside and outside the ballot box in twentyfirst century Britain.

To avoid operating at cross-purposes with youth studies and political science scholars, Politics, Protest and Young People begins by setting the stage for how concepts are applied and understood in the rest of the book. The discussion here will be familiar to readers of the Journal of Applied Youth Studies. Besides shedding light on why it is important not to lump all young people together into a homogeneous block (p. 27; see also p. 469), Pickard uses this early chapter to outline: (1) whom she means by 'young people'; (2) the inconsistent legislative boundaries surrounding young people; and, (3) the development of terms used to denominate young people, such as adolescents, teenagers, youngsters, youths, followed by generational labels, such as Millennials and Generation Z. With respect to (3), one might take issue with Pickard's decision to discard the term 'youths'. For Pickard, this term (especially, in the plural) 'tends to promote the "young people as a problem" narrative and are mostly inappropriate when writing about young people and political participation' (pp. 28, 31-42). Language matters when referring to young people, but the word 'youths', one may argue, should not be understood, per se, as a determinant as to how those identified as such must be seen. So, if it is the 'young-people-are-a-problem' narrative that is responsible for the perpetuation of negative stereotypes and generalisations about young people, is it necessary to jettison the term 'youths'?

The next three chapters provide a critical assessment of political participation since the 1960s, where, again, heterogeneity in young people's political acts is taken into account. Failing to appreciate the numerous ways to approach the study of young people's political participation may produce unrealistic results that frequently lead to the enduring 'stigmatisation of young citizens encapsulated in the stereotype of politically "apathetic" young people', Pickard convincingly argues (p. 73). She, here, builds on O'Toole et al. (2003: 53) who point out that 'researchers following an orthodox research design set the boundaries of what is to be considered as political participation. As such, if individuals are not participating in these ways, they are considered to be, more or less, apathetic'. 
Accompanied by an impressive series of tables and a substantial amount of data on young people's electoral behaviour, Chapters 6-10 demonstrate forcefully how youths, from the 1970s onwards, have been denied any real input or power, during which the electoral participation rate for young people has steadily declined (with the notable exception of the so-called 'youthquake' associated with the 2017 General Election, analysed in Chapter 10). In addition to the more obvious impact of polity, Pickard's meticulous research (e.g., p. 261) highlights various 'structural, macro, logistical, ideological and practical barriers' to electoral participation that lead to young people's political alienation, as well as ways to overcome these barriers, as shown in the extensive table (p. 251) outlining 75 measures to increase voter registration and voting among young people.

The last four chapters open the door to a discussion around non-electoral forms of political participation and protest, which, in part, is encapsulated and conceptualised through Pickard's term 'DIO politics' (Chapter 12, passim). Young people, Pickard observes, increasingly adopt a Do-ItOurselves attitude as they tend to bypass electorally-focused political structures. New forms of (often leaderless and non-hierarchical) political collectives are formed, which typically operate and spread locally and globally through digital technologies. Again, plenty of illustrations are provided to give insight into how young people reinvent non-electoral political participatory practices in creative and thoughtful ways, which, in turn, may impact governmental policies. These political collectives and practices are regularly dismissed as inauthentic, and, thus, downplayed, ignored or ridiculed. Rather than deriding the DIO political participation of young people, Pickard shows that many young people should be understood as 'reflexive political pioneers [...] using various capitals to act politically collectively through a variety of creative and conscious political actions' (p. 398).

The strengths of the book lie in its ability to bring together relevant data outlining young citizens' engagement in various electoral and non-electoral political participation, combined with its potential to provide practical measures for boosting electoral participation and decreasing political alienation across the youth demographic. This makes Politics, Protest and Young People not only relevant to students, academics and researchers within the fields of youth studies, sociology and political science; politicians, too, will find much to be gleaned from this book. At any rate, like many recent academic texts where young people are the protagonists, an overall aim of this book is to draw attention to the fact that youth voices are often ignored. I therefore encourage youth sociologists to pick up the baton and build on Pickard's superbly informative book by 
conducting interviews in which young people narrate their experiences of political participation and dissent in twenty-first century Britain.

\section{Reference}

O’Toole, T., Lister, M., Marsh, D., Jones, S. \& McDonagh, A. (2003), 'Tuning out or Left Out? Participation and Non-Participation among Young People', Contemporary Politics, 9(1): $45-61$. 